
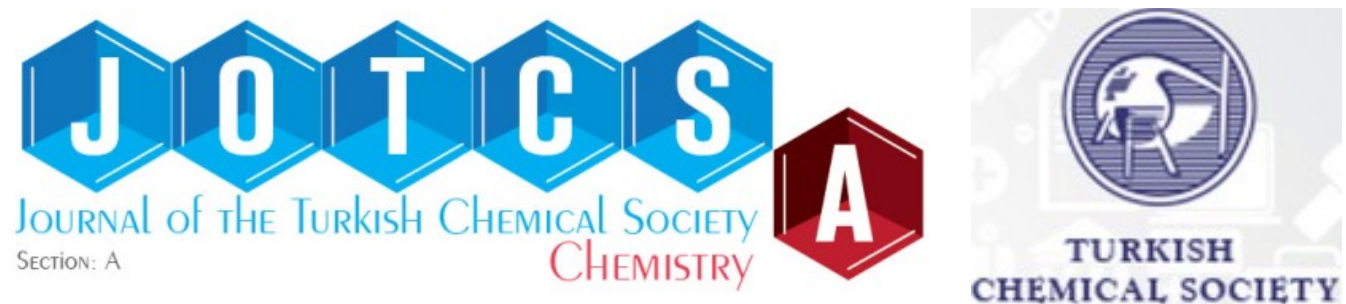

\title{
Radionuclide Potential of Holocene Sediments in the West of Marmara Sea (Turkey)
}

\author{
Zeki Ünal YÜMÜN ${ }^{*} \square$ and Erol KAM² \\ ${ }^{1}$ Namık Kemal University, Çorlu Engineering Faculty, Environmental Engineering Department, 59860 \\ Çorlu, Tekirdağ, TURKEY, zyumun@nku.edu.tr \\ ${ }^{2}$ Yildiz Technical University, Faculty of Arts and Sciences, Physics Department, Davutpaşa Campus, 34220 \\ Esenler/ İstanbul, TURKEY, erolkam@yildiz.edu.tr
}

\begin{abstract}
Radionuclides that cause radioactive pollution descend to the bottom in marine and water environments such as heavy metals and accumulate in bottom sediments. It is useful to determine the radionuclides in these environments to control the radionuclide release and its damage. Radioactive pollution can harm people's life directly or through the food chain. In this study, natural and artificial radionuclide values were measured in Recent sediment samples taken from the seabed in the western part of the Marmara Sea. Gamma spectrometry method was used in radionuclide examinations. In gamma spectrometry studies of sediments, values of radionuclides $\left({ }^{40} \mathrm{~K},{ }^{137} \mathrm{Cs},{ }^{226} \mathrm{Ra},{ }^{54} \mathrm{Mn},{ }^{95} \mathrm{Z}\right.$, and ${ }^{232} \mathrm{Th}$ ) were determined. Sea depths where 18 analyzed seafloor sediments are taken vary between $15-$ $50 \mathrm{~m}$. The determined radionuclide concentration activity values of the study area are ${ }^{137} \mathrm{Cs}(0.9-9.4$ $(\mathrm{Bq} / \mathrm{kg}))$, ${ }^{232} \mathrm{Th}(18.9-86(\mathrm{~Bq} / \mathrm{kg})),{ }^{226} \mathrm{Ra}(10-50(\mathrm{~Bq} / \mathrm{kg})),{ }^{40} \mathrm{~K}(24.4-670(\mathrm{~Bq} / \mathrm{kg})),{ }^{54} \mathrm{Mn}$ $(0.71-0.9(\mathrm{~Bq} / \mathrm{kg}))$ and ${ }^{95} \mathrm{Zr}(0.18-0.19(\mathrm{~Bq} / \mathrm{kg}))$. These values were correlated with the United Nations Scientific Committee on the Effects of Atomic Radiation (UNSCEAR). The ${ }^{226}$ Ra series, ${ }^{232} \mathrm{Th}$ series, and $40 \mathrm{~K}$ radionuclides accumulate naturally, and their concentrations increase gradually due to anthropogenic impurities. ${ }^{226} \mathrm{Ra}$ values obtained across the study areas are within normal limits according to UNSCEAR values. ${ }^{40} \mathrm{~K}$ and ${ }^{232} \mathrm{Th}$ values were higher than UNSCEAR values in all locations. ${ }^{137} \mathrm{Cs}(0.9-9.4(\mathrm{~Bq} / \mathrm{kg}))$ from almost all locations reveals a risky situation in terms of ambient conditions because this element cannot be found in the natural environment and can be found artificially as an end of radioactivity.
\end{abstract}

Keywords: ${ }^{40} \mathrm{~K},{ }^{137} \mathrm{Cs},{ }^{226} \mathrm{Ra},{ }^{54} \mathrm{Mn},{ }^{95} \mathrm{Z},{ }^{232} \mathrm{Th}$, radionuclide, Marmara Sea.

Submitted: March 02, 2020. Accepted: May 15, 2020.

Cite this: YÜMÜN ZÜ, KAM E. Radionuclide Potential of Holocene Sediments in the West of Marmara Sea (Turkey). JOTCSA. 2020;7(2):517-24.

DOI: https://doi.org/10.18596/jotcsa.696731.

*Corresponding author. E-mail: zyumun@nku.edu.tr.

\section{INTRODUCTION}

Humanity has lived with radiation continuously from the beginning of our existence. With the formation of the Earth, very long-lived (order of billion years) radioactive elements, inherently a part of nature, have created a natural and inevitably accepted natural radiation level in the environment (1).
Natural and anthropogenic radioactivity is related to the primary sources of radioactive composition encountered in marine, terrestrial, and atmospheric environments.

Natural airborne radiation is caused either by radioactive gases from various cracks in the earth (especially from radon gas) or by cosmic rays. The radioactivity in the soil is due to uranium, thorium, and other radioactive substances included in the 
decomposition series of those radioisotopes. Radiation in water is due to the interaction of the radioactive sources in both the air and the soil with water (2).

Natural radionuclide concentrations are continually increasing in terrestrial and mainly marine environments. The reason for that is the rapid increase in the use of artificial fertilizers, fossil fuels, detergents, and pesticides and also the proliferation of phosphate processing plants (3). The most critical radioactive substances found in natural waters are uranium, thorium, radium, radon, strontium, potassium, carbon, and hydrogen (4). Radionuclides that cause artificial radioactivity are spread to the environment as a result of radiological activities, radioactive waste heaps, or nuclear accidents. Although those activities create a variety of different radionuclides, the ones that play an essential role in the radiation exposure of humans are the products of diffusion and activation ( ${ }^{137} \mathrm{Cs}$ and others). Those radionuclides may lead to internal and external radiation damage in the human body. Therefore, the radioactivity levels in environmental samples must be measured with an acceptable error so that the exposure dose can be accurately assessed (5).

Nuclear weapons trials that began in 1945 and continue to date, along with the Chernobyl (1986) and Fukushima (2011) nuclear reactor accidents, have resulted in high levels of artificial radionuclides spreading to the atmosphere.

Among radionuclides spreading to the environment since 1945 are the long-half-life radionuclides, including ${ }^{14} \mathrm{C}$, ${ }^{137} \mathrm{Cs}$, and ${ }^{90} \mathrm{Sr}$, which are important for environmental and human health. Those radionuclides accumulate in the marine environment and the living body, damaging both living spaces and living things (6).

In Turkey, Aközcan (2012) (7) studied the distribution of natural radionuclide concentrations in sediment samples in Didim and Izmir Bay. In his study, the activity concentrations of ${ }^{238} \mathrm{U},{ }^{226} \mathrm{Ra}$, ${ }^{232} \mathrm{Th}$, and ${ }^{40} \mathrm{~K}$ in sediments collected from two different locations in the Aegean Sea have been defined. The highest activity concentrations of ${ }^{238} \mathrm{U}$ and ${ }^{232} \mathrm{Th}$ were observed in sediments from the Gulf of Izmir. The highest activity concentrations of ${ }^{40} \mathrm{~K}$ in sediments were measured from Didim (7). Aytaş et al. (2012)(8) evaluated thirty sediment samples from different distances along the Maritza and Tundja River. These samples were analyzed by gamma spectroscopy for ${ }^{238} \mathrm{U},{ }^{232} \mathrm{Th}$, and ${ }^{40} \mathrm{~K}$.
The measured average activity concentrations of ${ }^{238} \mathrm{U}$ and ${ }^{232}$ Th are above the world average, but the average activity concentration of ${ }^{40} \mathrm{~K}$ is within the world average value (8).

Natural and artificial radioactivity assessment of dam lakes sediments in the Çoruh River (Turkey) was studied by Kobya et al. (2015) (9). In the study, ${ }^{238} \mathrm{U},{ }^{232} \mathrm{Th},{ }^{40} \mathrm{~K}$, and ${ }^{137} \mathrm{Cs}$ activity concentrations were determined. The mean concentrations of ${ }^{238} \mathrm{U},{ }^{232} \mathrm{Th},{ }^{40} \mathrm{~K}$, and ${ }^{137} \mathrm{Cs}$ were found to be 15.8, 13.9, 551.5 and $18.1 \mathrm{~Bq} / \mathrm{kg}$ respectively in Deriner Dam Lake (zone 1); 3.7, 12.5, 473.8 and $6.8 \mathrm{~Bq} / \mathrm{kg}$ in Borçka Dam Lake (zone 2); 14.4, 30.0, 491.7 and $18.2 \mathrm{~Bq} / \mathrm{kg}$ in Muratlı Dam Lake (zone 3) was determined. The fact that the activity concentration values of radionuclide are maximum in the Deriner Dam Lake, where the sediment deposition is at its maximum level (9).

This study aims to determine natural and artificial radionuclide distribution in both intense industrialization and non-industrialized areas of the West of Marmara Sea by using gamma spectrometry and bring out the risky areas for human life.

\section{MATERIALS AND METHOD}

The study area covers the area between Silivri (Istanbul) and Tekirdağ-Gelibolu (Çanakkale) in the north and between Lapseki (Çanakkale) and Bandırma (Balıkesir) in the south in the Western Marmara Sea (Figure 1).

The bathymetry of the sea from which the samples were taken ranges from $20 \mathrm{~m}$ to $35 \mathrm{~m}$. In the Marmara Sea, the Anatolian (Southern Marmara) and Thrace (Northern Marmara) shores show different characteristics. Thrace shores, which meet the sea with large plateaus, feature gulfs (Tekirdağ and Silivri Gulfs) with wide arcs and beaches with small coves that have turned into lagoons. On the other hand, the Anatolian coast features the gulfs (Izmit, Gemlik, Bandirma, and Erdek) extending in the east-west and south-north directions and the islands (Kızıladalar, İmralı, and Marmara Islands) located in front of the rugged coasts (10). Core samples taken from 29 locations (sediment from the seafloor) were used in the study (Figure 2). The samples were taken between 15.10.2016 and 20.10.2016, and the coordinates and depth information of the samples are given in Table 1. 


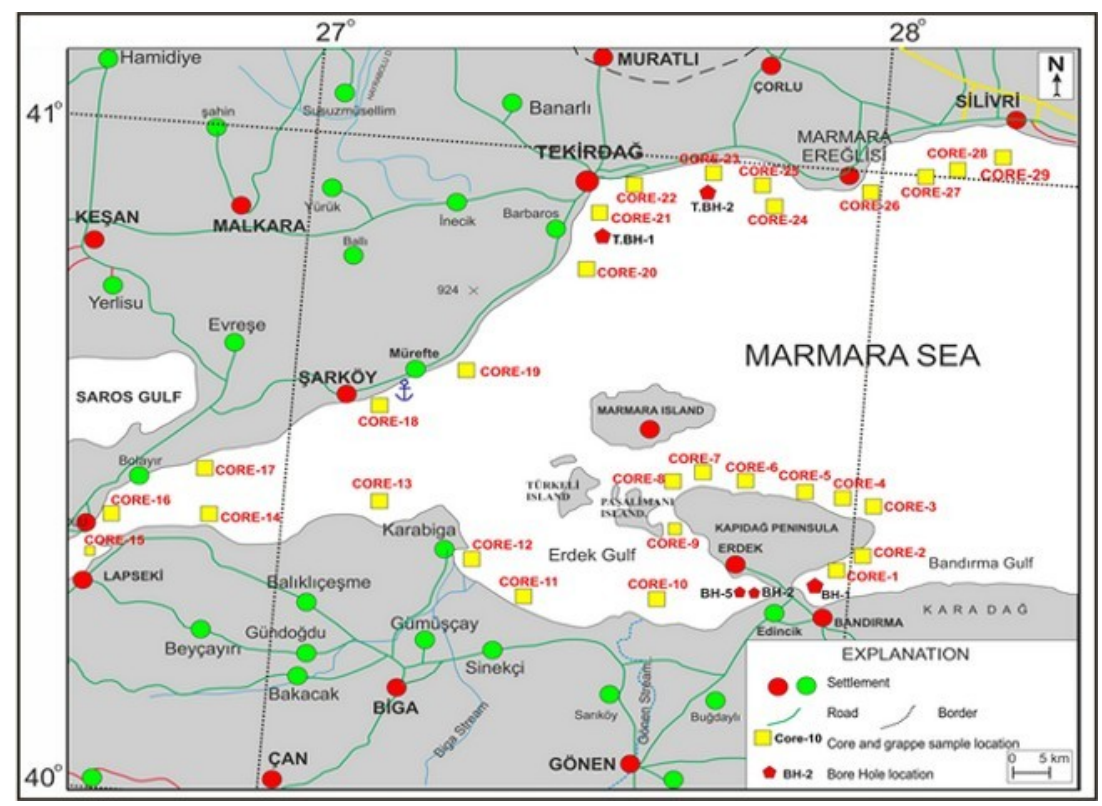

Figure 1. Location map of sample and study area.

Radionuclide analyses of the samples were made at the Çekmece Nuclear Research and Training Center. Samples were first dried at room temperature and prepared for analysis by sieving with 100-micron mechanical sieve. The samples were kept in the dry state for forty days were provided balance in radium, thorium, and other decomposition products. Concentration values of the radionuclides were analyzed using a Canberra GX5020 device.

The gamma activity peaks were: ${ }^{238} \mathrm{U}$ series, 609.3 keV; ${ }^{232} \mathrm{Th}$ series, $583 \mathrm{keV} ;{ }^{228} \mathrm{Ac}, 911.2 \mathrm{keV}$; ${ }^{226} \mathrm{Ra}, 185.7 \mathrm{keV}$; ${ }^{137} \mathrm{Cs}, 661.7 \mathrm{keV}$; and ${ }^{40} \mathrm{~K}$, $1460.8 \mathrm{keV}$. In the gamma spectrometry analysis method, gamma ray-emitting radionuclides that irradiate at the energy range of $40 \mathrm{keV}$ to 2000 keV are usually measured directly, without being separated from the sample matrix (such as air, water, soil, sediment, plant material, vegetable, and animal food.). Therefore, it is one of the most widely-used methods in the environmental analysis (5).

\section{RESULTS}

The range of radionuclide activity concentrations in the sediment samples, in $\mathrm{Bq} / \mathrm{kg}$, was $0.9-9.4$ for ${ }^{137} \mathrm{Cs}$; $18.9-86$ for ${ }^{232} \mathrm{Th}$; $10-50$ for ${ }^{226} \mathrm{Ra}$, and 24.4-670 for ${ }^{40} \mathrm{~K}$. Tables 2 and 3 present core sample radionuclide activities. The values were interpreted in comparison with the international average values as given in Table 4 (11).
In all locations, the analyses for ${ }^{40} \mathrm{~K}$ were obtained in the core samples, the ${ }^{40} \mathrm{~K}$ levels were above the world limits, whereas the $232 \mathrm{Th}$ levels were below the limit in eleven locations and above world standard in eighteen locations. The values of ${ }^{226} \mathrm{Ra}$ were above the limit value at only one location ( $\mathrm{K}$ $10,50 \mathrm{~Bq} / \mathrm{kg})$. It is noteworthy that the ${ }^{232} \mathrm{Th}$ values $(86-186 \mathrm{~Bq} / \mathrm{kg})$ reach the highest level in the Core-10 sample. One of the radioactive isotopes of cesium, ${ }^{137} \mathrm{Cs}$, which is an alkali metal with similar chemical properties to potassium, reaches the highest value $(9.4 \mathrm{~Bq} / \mathrm{kg})$ at the Core20 location. That isotope has a considerably long physical half-life of 30.17 years; therefore, it is considered to be biologically hazardous for the ecosystem (12). The distributions of artificial and natural radionuclides at sea may differ from region to region, depending on various factors. The number of radionuclides deposited in marine environments vary with the physical and chemical properties of the radionuclide, dry or wet accumulation pattern, and topographic and meteorological environmental conditions (13).

Therefore, numerical results obtained from sediment samples show large variations. Figures 2, 3,4 , and 5 show the distribution of radionuclides for all sample locations in the west of the Marmara Sea. Figure 2 shows the map of ${ }^{40} \mathrm{~K}$, and radionuclides have been produced with the kriging method. Similarly, Figure 3 shows ${ }^{226} \mathrm{Ra}$ and Figure 4 shows ${ }^{232} \mathrm{Th}$ and Figure 5 shows ${ }^{137} \mathrm{Cs}$ radionuclides. 
Table 1. Geographic coordinates of core samples.

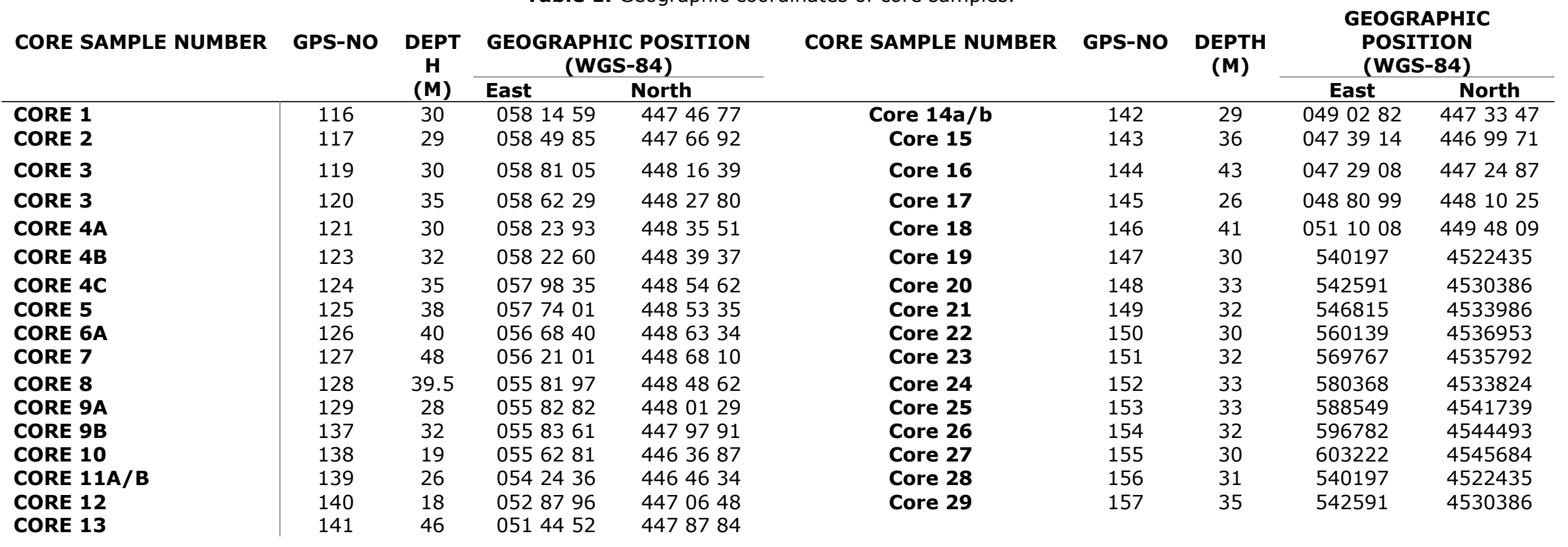


Table 2. Results of gamma spectrometric analyses of core samples.

\begin{tabular}{|c|c|c|}
\hline Sample & Radionuclide & Activity $\pm \mathrm{Bq} / \mathrm{kg}$ \\
\hline \multirow{4}{*}{ CORE-1 } & ${ }^{40} \mathrm{~K}$ & 490 \\
\hline & ${ }^{137} \mathrm{Cs}$ & 2.5 \\
\hline & ${ }^{226} \mathrm{Ra}$ & 30 \\
\hline & ${ }^{232} \mathrm{Th}$ & 42 \\
\hline \multirow{3}{*}{ CORE-2 } & ${ }^{137} \mathrm{Cs}$ & 1.9 \\
\hline & ${ }^{226} \mathrm{Ra}$ & 19.8 \\
\hline & ${ }^{232} \mathrm{Th}$ & 27.1 \\
\hline \multirow{3}{*}{ CORE-3 } & ${ }^{226} \mathrm{Ra}$ & 25 \\
\hline & ${ }^{232} \mathrm{Th}$ & 28 \\
\hline & ${ }^{40} \mathrm{~K}$ & 24.4 \\
\hline \multirow{3}{*}{ CORE-4 } & ${ }^{137} \mathrm{Cs}$ & 1.4 \\
\hline & ${ }^{232} \mathrm{Th}$ & 21.6 \\
\hline & ${ }^{54} \mathrm{Mn}$ & 0.71 \\
\hline & ${ }^{40} \mathrm{~K}$ & 470 \\
\hline \multirow{3}{*}{ CORE-5 } & ${ }^{137} \mathrm{Cs}$ & 1.8 \\
\hline & ${ }^{226} \mathrm{Ra}$ & 21.5 \\
\hline & ${ }^{232} \mathrm{Th}$ & 30 \\
\hline \multirow{4}{*}{ CORE-6 } & ${ }^{40} \mathrm{~K}$ & 450 \\
\hline & ${ }^{137} \mathrm{Cs}$ & 1.3 \\
\hline & ${ }^{226} \mathrm{Ra}$ & 27 \\
\hline & ${ }^{232} \mathrm{Th}$ & 26 \\
\hline \multirow{4}{*}{ CORE-7 } & ${ }^{137} \mathrm{Cs}$ & 1.1 \\
\hline & ${ }^{226} \mathrm{Ra}$ & 24 \\
\hline & ${ }^{232} \mathrm{Th}$ & 39 \\
\hline & ${ }^{95+} \mathrm{Zr}$ & 0.2 \\
\hline \multirow[t]{3}{*}{ CORE-8 } & ${ }^{137} \mathrm{Cs}$ & 1.1 \\
\hline & ${ }^{226} \mathrm{Ra}$ & 18.6 \\
\hline & ${ }^{232} \mathrm{Th}$ & 30 \\
\hline \multirow[t]{4}{*}{ CORE-9 } & ${ }^{40} \mathrm{~K}$ & 470 \\
\hline & ${ }^{137} \mathrm{Cs}$ & 0.9 \\
\hline & ${ }^{226} \mathrm{Ra}$ & 19 \\
\hline & ${ }^{232} \mathrm{Th}$ & 33 \\
\hline
\end{tabular}

Sample Radionuclide

\begin{tabular}{ccc} 
& & $\mathbf{\pm} \mathbf{~ B q} / \mathbf{~ k g}$ \\
\hline & ${ }^{137} \mathrm{Cs}$ & 3.5 \\
CORE-10 & ${ }^{226} \mathrm{Ra}$ & 50 \\
& ${ }^{232} \mathrm{Th}$ & 86 \\
& ${ }^{155} \mathrm{Eu}$ & 3.2 \\
& ${ }^{40} \mathrm{~K}$ & 670 \\
& ${ }^{232} \mathrm{Th}$ & 57 \\
& ${ }^{226} \mathrm{Ra}$ & 34 \\
CORE-11 & ${ }^{137} \mathrm{Cs}$ & 3.8 \\
& ${ }^{54} \mathrm{Mn}$ & 1.1 \\
& ${ }^{232} \mathrm{Th}$ & 49 \\
CORE-12 & ${ }^{226} \mathrm{Ra}$ & 28.2 \\
& ${ }^{137} \mathrm{Cs}$ & 4.9 \\
& ${ }^{232} \mathrm{Th}$ & 45 \\
CORE-13 & ${ }^{226} \mathrm{Ra}$ & 25.7 \\
& ${ }^{137} \mathrm{Cs}$ & 2.2 \\
& ${ }^{95} \mathrm{Zr}$ & 0.27 \\
& ${ }^{40} \mathrm{~K}$ & 470 \\
CORE-14 & ${ }^{232} \mathrm{Th}$ & 36 \\
& ${ }^{226} \mathrm{Ra}$ & 25.2 \\
& ${ }^{137} \mathrm{Cs}$ & 0.90 \\
& ${ }^{137} \mathrm{Cs}$ & 3.2 \\
CORE-15 & ${ }^{226} \mathrm{Ra}$ & 19.5 \\
& ${ }^{232} \mathrm{Th}$ & 36 \\
& ${ }^{40} \mathrm{~K}$ & 600 \\
& ${ }^{137} \mathrm{Cs}$ & 4.7 \\
CORE-16 & ${ }^{226} \mathrm{Ra}$ & 24.9 \\
& ${ }^{232} \mathrm{Th}$ & 37 \\
& ${ }^{137} \mathrm{Cs}$ & 1.6 \\
& ${ }^{226} \mathrm{Ra}$ & 18.9 \\
& ${ }^{232} \mathrm{Th}$ & 26 \\
& & \\
& &
\end{tabular}

Table 3. Results of gamma spectrometric analyses of core samples (continuation of Table 2)

\begin{tabular}{|c|c|c|c|c|c|}
\hline Sample & Radionuclide & Activity $\pm \mathrm{Bq} / \mathbf{k g}$ & Sample & Radionuclide & $\begin{array}{l}\text { Activity } \\
\pm \mathrm{Bq} / \mathbf{k g}\end{array}$ \\
\hline \multirow{3}{*}{$\begin{array}{c}\text { CORE- } \\
18\end{array}$} & ${ }^{137} \mathrm{Cs}$ & 4.8 & \multirow{3}{*}{$\begin{array}{c}\text { CORE- } \\
24\end{array}$} & ${ }^{226} \mathrm{Ra}$ & 10 \\
\hline & ${ }^{226} \mathrm{Ra}$ & 29 & & ${ }^{232} \mathrm{Th}$ & 21 \\
\hline & ${ }^{232} \mathrm{Th}$ & 36 & & ${ }^{40} \mathrm{~K}$ & 550 \\
\hline \multirow{4}{*}{$\begin{array}{c}\text { CORE- } \\
19\end{array}$} & ${ }^{40} \mathrm{~K}$ & 650 & \multirow{4}{*}{$\begin{array}{l}\text { CORE- } \\
25\end{array}$} & ${ }^{137} \mathrm{Cs}$ & 1 \\
\hline & ${ }^{137} \mathrm{Cs}$ & 2.3 & & ${ }^{226} \mathrm{Ra}$ & 22 \\
\hline & ${ }^{226} \mathrm{Ra}$ & 27.9 & & ${ }^{232} \mathrm{Th}$ & 38 \\
\hline & ${ }^{232} \mathrm{Th}$ & 39 & & ${ }^{95+} \mathrm{Zr}$ & 0.19 \\
\hline \multirow{4}{*}{$\begin{array}{c}\text { CORE- } \\
20\end{array}$} & ${ }^{40} \mathrm{~K}$ & 630 & \multirow{4}{*}{$\begin{array}{c}\text { CORE- } \\
26\end{array}$} & ${ }^{40} \mathrm{~K}$ & 480 \\
\hline & ${ }^{137} \mathrm{Cs}$ & 9.4 & & ${ }^{232} \mathrm{Th}$ & 24 \\
\hline & ${ }^{226} \mathrm{Ra}$ & 20.5 & & ${ }^{226} \mathrm{Ra}$ & 19.2 \\
\hline & ${ }^{232} \mathrm{Th}$ & 35 & & ${ }^{137} \mathrm{Cs}$ & 0.8 \\
\hline \multirow{3}{*}{$\begin{array}{c}\text { CORE- } \\
21\end{array}$} & ${ }^{137} \mathrm{Cs}$ & 3.7 & \multirow{3}{*}{$\begin{array}{c}\text { CORE- } \\
27\end{array}$} & ${ }^{137} \mathrm{Cs}$ & 1.3 \\
\hline & ${ }^{226} \mathrm{Ra}$ & 20.6 & & ${ }^{226} \mathrm{Ra}$ & 16.1 \\
\hline & ${ }^{232} \mathrm{Th}$ & 30 & & ${ }^{232} \mathrm{Th}$ & 21.7 \\
\hline \multirow{3}{*}{$\begin{array}{c}\text { CORE- } \\
22\end{array}$} & ${ }^{137} \mathrm{Cs}$ & 5.1 & \multirow{3}{*}{$\begin{array}{c}\text { CORE- } \\
28\end{array}$} & ${ }^{40} \mathrm{~K}$ & 580 \\
\hline & ${ }^{226} \mathrm{Ra}$ & 27 & & ${ }^{137} \mathrm{Cs}$ & 1 \\
\hline & ${ }^{232} \mathrm{Th}$ & 20.7 & & ${ }^{226} \mathrm{Ra}$ & 18.1 \\
\hline \multirow{3}{*}{$\begin{array}{c}\text { CORE- } \\
23\end{array}$} & ${ }^{137} \mathrm{Cs}$ & 1.7 & \multirow{3}{*}{$\begin{array}{c}\text { CORE- } \\
29\end{array}$} & ${ }^{232} \mathrm{Th}$ & 24.8 \\
\hline & 226Ra & 13.7 & & ${ }^{226} \mathrm{Ra}$ & 20.9 \\
\hline & ${ }^{232} \mathrm{Th}$ & 18.9 & & ${ }^{232} \mathrm{Th}$ & 31 \\
\hline
\end{tabular}


Table 4. International average values of radionuclides (11)

\section{Radionuclides}

\begin{tabular}{l|r}
\multicolumn{2}{c}{ Values } \\
\hline${ }^{232} \mathrm{Th}$ & $30 \mathrm{~Bq} / \mathrm{kg}$ \\
${ }^{226} \mathrm{Ra}$ & $35 \mathrm{~Bq} / \mathrm{kg}$ \\
${ }^{40} \mathrm{~K}$ & $400 \mathrm{~Bq} / \mathrm{kg}$
\end{tabular}

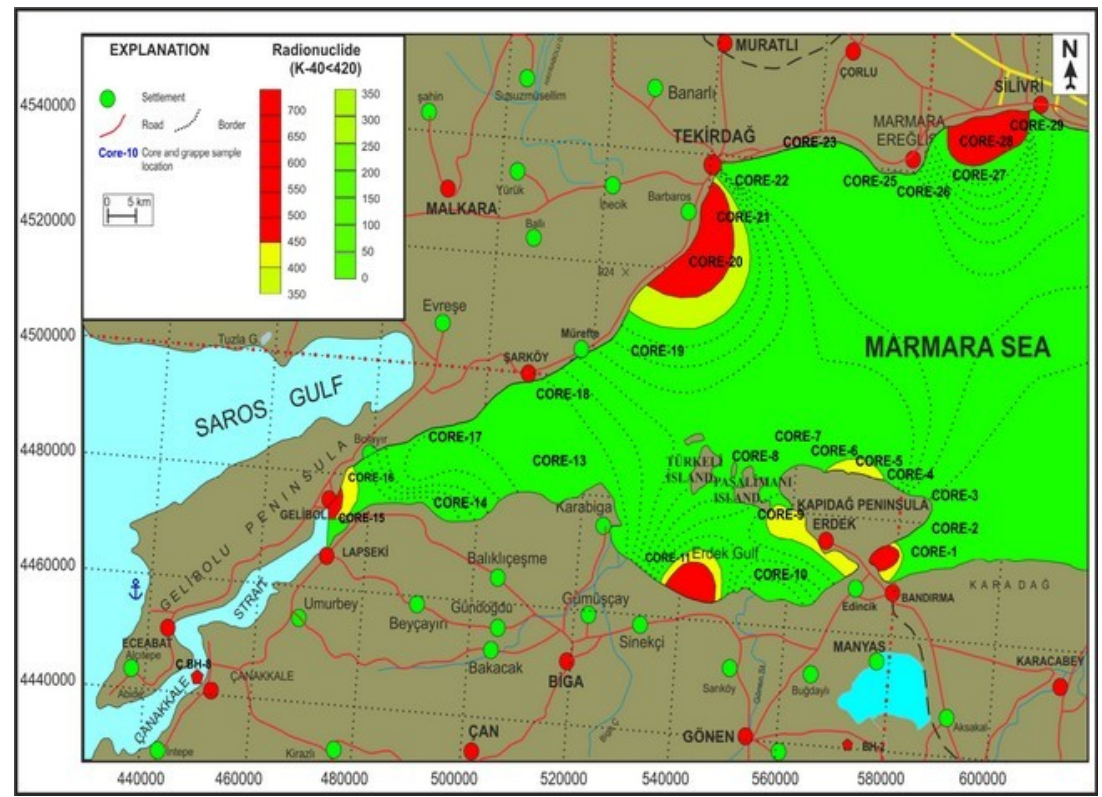

Figure 2. Distribution of the activity concentrations of ${ }^{40} \mathrm{~K}(\mathrm{~Bq} / \mathrm{kg})$

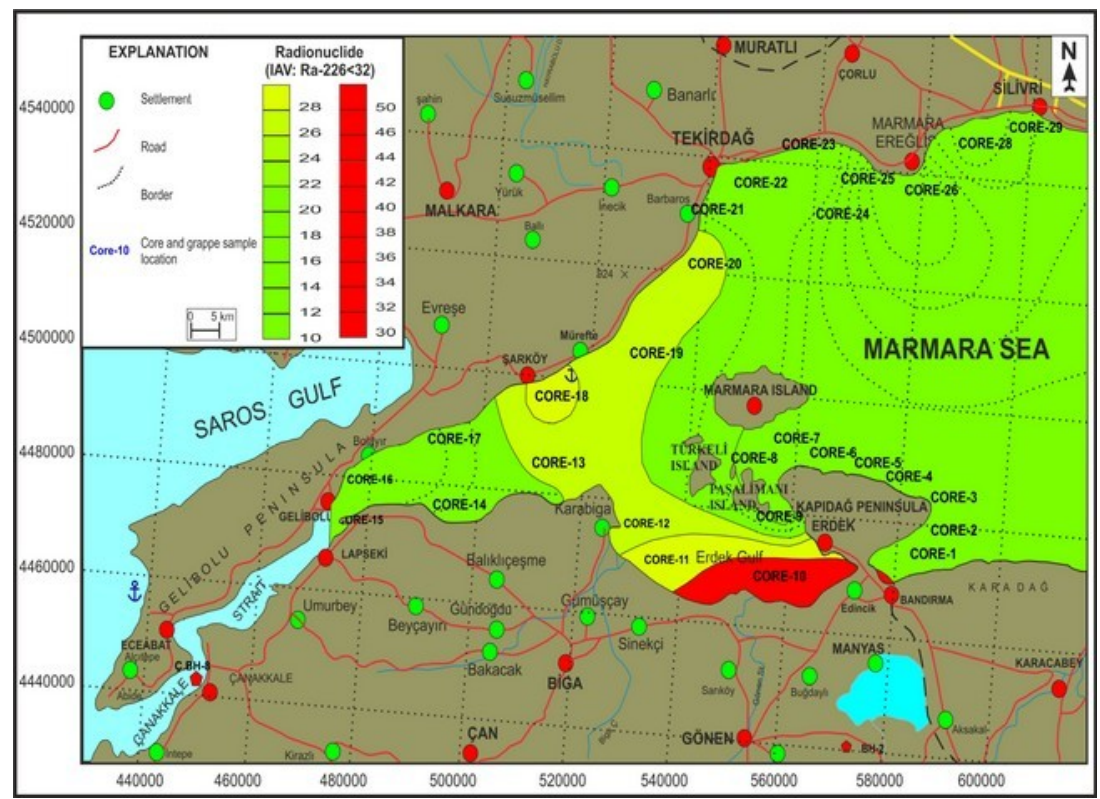

Figure 3. Distribution of the activity concentrations of ${ }^{226} \mathrm{Ra}(\mathrm{Bq} / \mathrm{kg})$. 


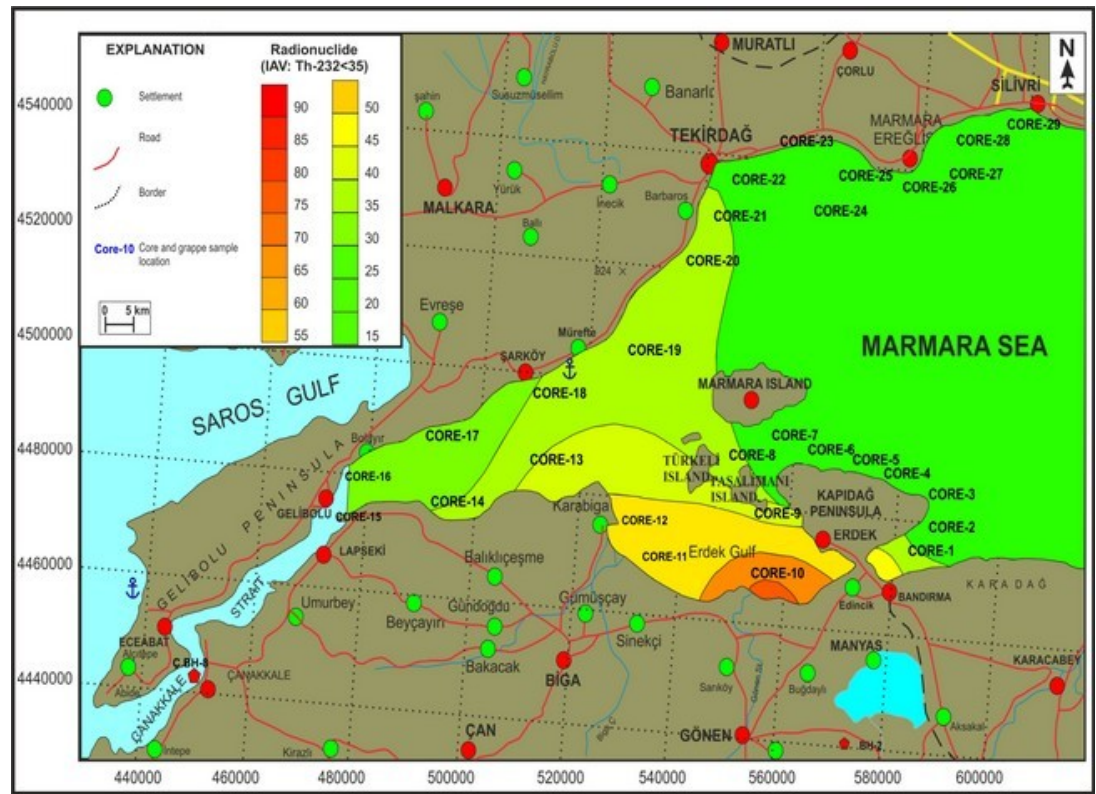

Figure 4. Distribution of the activity concentrations of ${ }^{232} \mathrm{Th}(\mathrm{Bq} / \mathrm{kg})$.

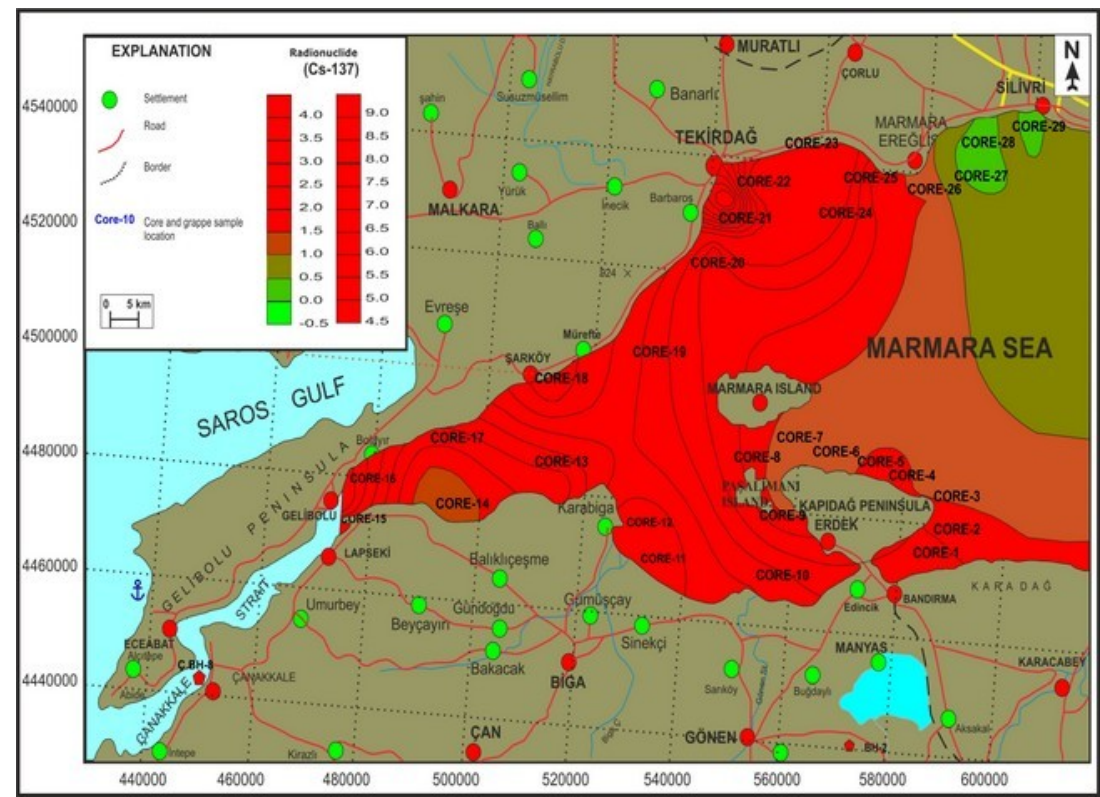

Figure 5. Distribution of the activity concentrations of ${ }^{137} \mathrm{Cs}(\mathrm{Bq} / \mathrm{kg})$.

\section{DISCUSSION AND CONCLUSION}

In this study, core samples were collected from 29 different locations in the Marmara Sea for radioactivity analyses for ${ }^{40} \mathrm{~K},{ }^{232} \mathrm{Th},{ }^{137} \mathrm{Cs},{ }^{226} \mathrm{Ra}$, ${ }^{54} \mathrm{Mn}$, and ${ }^{95+} \mathrm{Zr}$ on the western coast of the Sea of Marmara. The Gamma Spectrometric Analysis method was used to determine the radioactivity properties of the sediments. The radionuclide concentration activity values in the sediment samples obtained from the locations, in $\mathrm{Bq} / \mathrm{kg}$, were ${ }^{137} \mathrm{Cs}, 0.9-9.4 ;{ }^{232} \mathrm{Th}, 18.9-86 ;{ }^{226} \mathrm{Ra}, 10-50$; ${ }^{40} \mathrm{~K}$, 24.4-670; ${ }^{54} \mathrm{Mn}, 0.71-0.9$; and ${ }^{95} \mathrm{Zr}, 0.18-$ 0.19 . These values were compared with data from the Turkish Atomic Energy Agency (TAEK) and the United Nations Scientific Committee on the Effects of Atomic Radiation (UNSCEAR), and environmental analysis was also carried out. As a result of the analyses ${ }^{40} \mathrm{~K}$ values were found to be zero in Core-2, Core-3, Core-4, Core-7, Core-8, Core-10, Core-12, Core-13, Core-15, Core-17, Core-18, Core-21, Core-23, Core-24, Core-27, and Core-29. The ${ }^{137} \mathrm{Cs}$ value was zero in Core-3 and Core-24, whereas it was determined to be 9.4 (Bq/ $\mathrm{kg}$ ) in Core-20. In the Core-11 sample taken from the Sea of Marmara (between Gönen Creek and Karabiga), the ${ }^{40} \mathrm{~K}$ value was higher than those of other locations and higher than the average world value. On the contrary, ${ }^{226} \mathrm{Ra}$ values measured in all the core samples were below the limit values. 


\section{ACKNOWLEDGMENTS}

The author thanks Yümün Mühendislik Ltd. Şti for their studies on drilling and core sampling and Melike ÖNCE, Sevinç YÜMÜN for the preparation of the samples in the laboratory and also for the separation studies of other fossils.

\section{REFERENCES}

1. TAEK. Radyasyon Kaynakları. Web. http://www.taek.gov.tr/ogrenci/r05.htm Turkish); 2012

2. Görür Ş. Investigation of the Relationship Between Environmental Radioactivity and Radioactivity in Dental Specimens. Cukurova University Institute Of Science Sciences, Graduate thesis. 2006; 1-74.

3. Topçuoğlu S. Radioactive Pollution of Seas. Web. http://www.gelbalder.org/ literatür/6238deniz-kirliligi-analiz-yontemleri-ilgili-uluslar-arasisozlesmeler-2.html; 2012.

4. Tekirdağ Valiliği. Tekirdağ Province Environmental Status Report. T.C. Tekirdağ Governorship Provincial Environment and Forestry Directorate 285-286. 2009.

5. Ayçik GA, Onat NB, Ertürk MK, Topçuoğlu S, Köksal G, Yaşar S, Güngör N. Sampling, measurement and analysis methods for monitoring environmental radioactivity, Turkish Atomic Energy Authority. 2000.

6. Ergül HA. Investigation of some heavy metal, radionuclide, organic carbon and chlorophyll-a levels of sedimenting material in Oxide Zone in Trabzon region of Black Sea. PhD Thesis, Karadeniz Technical University Institute of Science and Technology, Department of Biology. 2004.

7. Aközcan S. Distribution of natural radionuclide concentrations in sediment samples in Didim and Izmir Bay (Aegean Sea-Turkey), Journal of Environmental Radioactivity. 2012; 112: 60-63.

8. Aytaş Ş, Yusan $S$, Aslani MA, Karali T, Turkozu D, A, Gök C, Erentürk S, Gökçe $M$, Oğuz KF. Natural Radioactivity of Riverbank Sediments of the Maritza and Tundja Rivers in Turkey. Journal of Environmental Science and Health, Part A. 2012; 47: 2163-2172.

9. Kobya Y, Taşkın H, Yeşilkanat CM., Varinlioğlu A, Korcak S. Natural and Artifical Radioactivity Assessment of Dam Lakes Sediments in Çoruh River, Turkey. Journal Radioanal Nucleid Chemical. 2015; 303: 287-295.

10. Bursa GC. Marmara Denizi. Web. http://bgc.org.tr/ansiklopedi/marmara-denizi.html [10].2015.

11. UNSCEAR. Sources and Effects of Ionizing Radiation. United Nations Scientific Committee On The Effects Of Atomic Radiation. Report to General Assembly with Scientific Annexes. United Nations, New York. 2000; 1, 1-659.

12. Aközcan S. Cs-137 Concentrations in Sediment and Waters of Büyük Menderes River and Dilek Peninsula Büyük Menderes Delta. Ekoloji. 2011; 20 (81): 55-60.

13. Aközcan S. Monitoring of Some Radionuclide and Heavy Metal Levels in Sediment, Sea Water and Different Marine Organisms in Didim and İzmir Bay (Turkish with English Abstract). PhD Thesis, Ege University Institute of Science, Department of Nuclear Science, İzmir. 2009. 